\title{
Consolatory Literature of the English Recusants
}

\author{
JOSEPHINE EVETTS SECKER
}

\section{The consolatio: early developments and the influence of Boethius}

The consolatio is said to have begun in the poetry of Homer and been given final literary form by the Greek orator, Crantor (330-268). Adopted by the Greek Fathers (Basil, the Gregories) it proved adaptable to the needs of the growing Church. In the Latin tradition, it was further developed by writers such as Cyprian and Augustine and by non-Christian writers, especially Seneca, while both Cicero and Quintillian formulated rules for its composition. I do not wish to deal with the origins of the form; ${ }^{1}$ it is enough to recognize that it is an ancient genre exploited by poets, philosophers, orators and religious pastors and that it is accessible to all kinds of adaptation. Although the original consolatio represented a philosophical attempt to come to terms with man's mortality, it expanded in the writings of the Cappadocian fathers to deal with the whole question of adversity, becoming more than a literature of condolence. It had been the custom to call a philosopher to the scene of a mishap to provide instant explanation and comfort. This habit seems to have been taken over by Popes and pastors in the early Church by written communication, as in, for example, letters written to communities on the removal of a well-loved bishop and the large body of literature written for those suffering persecution.

It is important to remember that there is a pagan as well as a Christian tradition of consolatio, and both are reflected in the works considered here. It seems to me legitimate to begin with Boethius, who is accessible to both kinds of interpretation and whose ideas feed into both streams of consolatory thought in English. Since the translation by King Alfred of the Consolation of Philosophy, which provided one of our earliest vernacular works, England has seemed Boethius' natural domicile. He has been esteemed the intellectual vade mecum of the Middle Ages, and his spiritual influence persisted throughout the Reformation. The historical relevance of his life was reinforced for Catholics by its uncanny likeness to that of Thomas More. Whatever modern scholars may say about either figure, to 
post-Reformation Catholics they were both scholar-statesmen, poets and theologians, and both were martyrs who died for the truth. More is of course familiar with Boethius' work, referring to it on occasion and even presenting it visually in the Nostell portrait. However, More points to the insufficiency of the comfort of Philosophy in times of actual persecution when theoretical argument must give way to active meditation, though he is aware of the power of secular, stoic consolation. Renaissance man was generally quite happy to read Christ into the Consolation of Philosophy, even though Boethius makes no specific reference to Him. Boethius' text became the standard handbook of solace, and it had magnetic attraction for Renaissance men in distress, as attested by Dante himself who looked to the Consolation expecting to find silver, but finding gold.

Volumes of Boethius came from European presses regularly, ${ }^{2}$ though in England, after Chaucer's translation of his beloved 'Boece," there was little before the Reformation. To Englishmen suffering for their faith, it became a precious work, often quoted, its spirit pervading much of the poetry in manuscript and printed collections. Recognizably Boethian are such lyrics as Henry Parker's "Bedtime Peace,"3 Thomas Vaux's "Of a Contented Minde" 4 and Richard Verstegan's "Fort of Solitude," as indeed is More's own "Against my Lady Fortune."" 6 These poems represent the secular wisdom of the tradition, though they were written by committed Christians prepared to suffer severe punishments for their faith. Parker refers specifically to Seneca, and both he and Verstegan echo Cicero's thought on self-sufficiency. Man is urged to rise above the chances of Fortune, to choose poverty, since wealth puts the "mynde out of quyate." They all affirm with Verstegan that "true freedom is enclos' $d$ / In circuite of the mynde" and take comfort in this paradox, as did Boethius in his confinement.

Boethius' book has associations with English prisoners. We are told that Edward Barlow read the work in prison and Sir Harry Coningsby translated it there "for my owne alleviation."" Two temporary residents of the Tower prepared the text: the Protestant Sir Richard Grahame translated $\mathrm{it}^{8}$ and a Latin adaptation was made by John Leslie, Bishop of Ross, dedicated to Mary, Queen of Scots. ${ }^{9}$ Colville's earlier translation dedicated to Queen Mary ${ }^{10}$ was aimed to lead men to a life of contemplation, and Queen Elizabeth herself translated it near the end of her life (1598). In 1609 one I.T. (Michael Walpole) saw it as a way to "felicitie" and presented Boethius as a Christian martyr. ${ }^{11}$ Nicholas Caussin's popular work, translated beautifully as The Holy Court by Sir Thomas Hawkins, has a long section on Boethius, also treating him as the ideal pious statesman who became a Christian martyr. ${ }^{12}$ All these works made Boethius easily accessible in the vernacular, and to recusants and Protestants alike, he was clearly a non-controversial Christian comforter. Perhaps more important to Catholics, however, were the 
imitations and developments of consolatory writing that work out a special Christian, Catholic and English philosophy of tribulation. In some cases, these works are no longer strictly consolationes, but even when this is so, the writers are aware of the tradition and use it as a relevant, if distant, model.

\section{Survey of Recusant consolatory writing, 1534-1610}

The recusant's awareness of the precedent for his condition is reflected by the translation of an Epistle Consolatory: Of an Auncient Pope in 1576. ${ }^{13}$ Pope Clement's letter could be aptly appropriated by the persecuted of the English flock. It demonstrates the main purpose of Christian consolatio. $\mathrm{He}$ assures his children of his concern and his sharing in their torment; he explains the purpose of their suffering and exhorts them to steadfastness, which, he promises, will be rewarded.

Thomas More's Dialogue of Comfort has a different emphasis. He urged that "euery man \& euery woman both, appoynt with goddes helpe in their owne mynd beforehand what thyng they intend to do yf the very worst fall." "14 His biographers suggest that his motive was "to stirre and prepare the mindes of englishe men manfully and couragiously to withstande ... the imminent and open persecution whiche he foresawe." ${ }^{15}$ His is the earliest English consolation, written in the Tower while awaiting his death in 1534, and I am assuming, at the very least, that subsequent recusant writers were closely familiar with More's work. Bishop Fisher's Spirituall Consolation is a short and more personal work, addressed to his sister - also from the Tower. ${ }^{16}$ Thomas Hide's Consolatorie Epistle to the Afflicted Catholics was published in 1579, and Persons' Epistle of the Persecution of Catholikes of England, in $1582 .{ }^{17}$ In 1587 appeared both $A$ Consolatory Letter to all the Afflicted Catholikes by H.B. and Southwell's Epistle of Comfort. ${ }^{18}$ Dealing with many of the same themes, there follows in 1596 Triumphs over Death: or a Consolatorie Epistle for afflicted minds, in the affects of dying friends, a strictly traditional consolation. ${ }^{19}$ Consolatory themes appear incidentally in works such as Persons' Christian Directory and in such devotional writers as Luis de Granada. ${ }^{20}$ In addition there is much pamphlet-like material that shows the formal consolation much reduced and used in ad hoc attempts to cope with emergent circumstances. Such is Allen's True, Sincere and Modest Defence of English Catholikes that suffer from their faith and his Briefe History of the glorious Martyrdome of XII reverend Priestes. ${ }^{21}$ Michael Walpole's Briefe Admonition to all English Catholikes also sets out to give comfort, and there is a rather touching and, in its own way, eloquent document by one I.R.P., probably John Floyd, $A$ Word of Comfort. Or a discourse concerning the late lamentable accident of the fall of a roome at a Catholike sermon in the Blackfriars that might also be considered within the extended consolatory genre. ${ }^{22}$ Poetry from printed and manuscript sources 
reflects the tradition, both isolated lyrics and substantial works such as Ralph Buckland's original psalms, Seaven Sparkes of the Enkindled Soule or Thomas Pounde's "The Cheerer: A Consolation to Afflicted Catholykes." ${ }^{23}$ In relation to the above works, I should perhaps mention the pertinent and popular book, Seneca's De Remediis, translated in 1547 as Remedyes agaynst all Casuall Chaunces; and thoroughly Senecan in argument and manner is a short work by Erasmus, $A$ Comfortable exhortacion against the chances of death, which also identifies comforts as remedies. ${ }^{24}$ Protestant writers wrote consolations in the same manner, it might be added, when they were the persecuted minority, as those of John Scory, George Joye and John Knoxe himself testify. ${ }^{25}$

\section{Literary form: Epistle and Dialogue}

As the titles suggest, the most popular form is the epistle or the dialogue, the latter Socratic device being most traditional but the former most commonly used in Christian writings. The history of the epistle is a study in itself, particularly as it relates to the Church. The classical epistolary discourse became the vehicle for communication and persuasion as travel became easier and politics more international. Though they could remain personal, letters came increasingly to be addressed to a group or a non-specified audience to whom the contents might prove beneficial. Southwell alludes to this practice in his opening:

It hath bene alwayes a laudable custome in Gods Church, for such as were afflicted in time of persecution not onlye by continuall prayer, and good works, but also by letters \& bookes to comforte one another. (Ep. p.3)

Aware that many other epistles are being written, he offers his as but another bit of light in the foggy night of heresy.

Boethius uses the dialogue effectively not only to portray the differing points of view between himself and Lady Philosophy but also to register the ebb and flow of argument pulling him from desolation to contentment. King Alfred's translation sustains the allegorical exchange between "Wisdom" and "Mind" but Thomas More, significantly, employs two fallible and struggling human beings, Vincent and Anthony, to wrestle with political, moral and theological realities. Several poems also use the dialogue form, varying the personae. Such is Anthony Copley's "The Discouraged Soul and the Angel of Good Cheer: A Dialogue" and the brief poem in Alfield's Reporte, "A Dialogue between a Catholike and Consolation." ${ }^{26}$ This poem is included among panegyrics on the life and martyrdom of Campion, and it questions the waste of such glorious young men. Consolation urges "Dispaire thou not thou seely mournful wight" and demon- 
strates the efficacy of suffering and the abundance of zealous young men ready to follow Campion's example. The perplexed Catholic finally accedes:

Fiat voluntas Dei then say I,

We owe a death, and once we needes must dy.

In other works where there is no actual dialogue, there is always an implied listener, an audience whose needs and objections are being met.

Recusant literature of consolation draws on the conventional forms and topoi of the genre, and builds on that foundation a theological superstructure of arguments, counsels and promises of comfort for the Christian facing death and adversity, especially in a political context. ${ }^{27}$

\section{Adversity: human experience and divine purpose}

In the Church of St. Gregory in Rome there is an inscription on the tomb of an Englishman which says that he "left England because he could not live in his country without the Faith and having come to Rome, died there because he could not live apart from his country." This was the dilemma of "the church under the cross," and much was written to meet the needs of such men. ${ }^{28}$ In an age that was becoming more sophisticated in its interest in, and understanding of, human psychology, we can expect an inward-looking and analytical literature, reflecting Hamlet's observation that nothing is ill but thinking makes it so ${ }^{29}$ It reflects, too, the prevailing humanist concern with human happiness. ${ }^{30}$ Against this background these writers encourage each other and teach men how to endure, as indeed does Shakespeare in his later characters, who, like King Lear, are often "trained in the school of adversity." 31

Though the quality of writing varies, the contents remain constant. In presenting the nature and purpose of suffering, all agree that it represents the fundamental pattern of Christian experience and is something to be desired. They all insist that adversity is better for man than prosperity - so much so that if God does not provide it, it should be self-inflicted. It is a matter of justice, not punishment, claims More, and Southwell remarks that when a man considers his sin he "hath rather cause to maruaile why he is not in hel than why he is in prison" (Ep. p. 76). Tribulation then is a demonstration of God's mercy that makes man run to Him. For Hide it is a gift from God, and for Southwell, Christ's last will and testament bequeathed to His friends. It is also a sign that a man is of Christ's true flock. Hide distinguishes between the troubled love of the saints on earth and the quiet love of those in heaven, an idea further developed by Granada who insists 
there is nothing more precious to God than "the troubled afflicted love of a just person, that is tried with adversitie, affliction and tribulation." ${ }^{32}$ God is "more desirous to have us affectionate, then fortunate children," claims Southwell, and so "delighteth more to see our torturings, rackinges, chaynes, and imprisonments for his sake" (Ep. p. 33). But we should not condemn God, the husbandman, for delighting in man's passion, because unless a seed fall into the ground and die, it cannot live, he argues. This is a commonly used gospel image developed at length by H.B. in his Consolatory Letter (p. 104).

In the Christian Directorie, Persons demonstrates how tribulation is good for man by using the example of David, who withstood temptation in adversity but fell in time of prosperity. Tribulation is unavoidable for Christians he insists: Christ promised it and the testimony of Scripture and the example of the Saints show this promise being fulfilled. It is purgatory on earth to assure bliss hereafter. Hawkins translates effectively Caussin's summary of the "fruites that might be derived from tribulation when it is well managed":

\begin{abstract}
Prosperity . . . is windy, open, slippery \& inconsiderate.
Adversity .... is sober, reserved, prudent and circumspect; the one under apparences of felicities, bringeth us an infinity of lyes, the other is ever grave \& sincere; the one deceaveth us, the other instructeth us; the one blindeth us; the other enlighteneth us; the one polluteth us; the other purifyeth us; the one charmeth us and tyeth up our understanding, the other enfranchiseth us; the one separateth us from our soveraigne good, and maketh us fall into a thousand sortes of vanityes, the other draweth us back, as with a hooke, to the consideration of eternity; one createth for us many flatteries, the other discovereth unto us many true friends. (p. 452).
\end{abstract}

The mistrust of prosperity reinforces the contemptus mundi theme that is central to consolation argument. Granada's meditation " Of the miseries of this life" (Tewsdaie Night) claims that they are "ordeyned ... to withdrawe our hartes from the inordinate love of this lyfe." Several writers repeat St. Ambrose's explanation of adversity through the image of the mother anointing her breast with aloes to wean her infant from her comforts. Southwell comments that if life were allowed to be sweet, man would delay on the way; misery at least makes him hurry to the next life. All these works document the ills and misery of life in conventional terms. To all, it is a vale of tears. Granada argues, typically, that man is "farre more prompt and readie .... to pewlinge and weepinge, then to ioye and mirth" (Tewsdaie Night). In addition to the natural misery man is heir to, abnormal disasters such as earthquakes and storms speak to man of his vulnerability. God also designs particular adversities to draw men to himself, strengthening the faithful and bringing the apathetic to repentance. These are often a 
last resort, following many unsuccessful "embassyes of love.” Writing in a medieval mode, Southwell dramatizes Christ as the "faithfull paramour of our soule, hanging in most rufull manner naked, wounded and redye to dye upon the Crosse":

\begin{abstract}
Tell my beloued that I languishe for love. And we most ungratefullye have refused his messengers.

He hath shewed us his feete nayled to attend our comminge, his side open to geve us entrance, his armes stretched forth redye to embrace us, his head inclined to afford us the kisse of peace . . . But we . . . have contemned all his inuitings. . . . But seing that he cannot moue us with so many griefes susteyned in our behalfe, he obscureth the sonne of our comfortes, he sendeth earthquakes of tribulations, he maketh the graues open . . . to wynne in a maner by force, sith by love he coulde not . . . (Ep. 18)
\end{abstract}

Here man's sin is ingratitude, and all writers agree that the major reason for tribulation is punishment for sin, and even so it is far less than man deserves. H.B. is the only writer to castigate Catholics for their lack of fervour and unwillingness to accept persecution. He laments "the golden dayes of those first Christians among whome the precious blood of our Saviour was yet warme," for they were zealous to suffer "all kinde of exquisite and grevous tormentes." He asks God to kindle the devotion of "this our dull age and dead season" so that men would not need so much encouragement and consolation (p. 4).

Several writers imply that God allows certain events because they provide good publicity for the cause. Both Southwell and Persons evaluate martyrdom as news, at home and abroad, making men curious and compelling belief. It has always been so. If a Stephen had not been stoned to death, the Church would not have had a St. Paul. But the ultimate reason why God sends suffering is, according to Persons, simply "that it pleseth him best so" (Dir. p. 641), a sentiment that would certainly find no place in any consolation of philosophy.

This then is the pattern of Christian life, documented in Scripture and Church history. Every life must move between the rod that corrects and the staff that supports, between Gethsemane and Tabor. The favourite models are "Job's calamitous case and dolefull dayes uppon a dunghill"' (Hide p. 83) and the Virgin Mary. Southwell claims that "even our blessed Lady . . . was throwne downe as deep in temporal miseries as she was advanced in spirituall honours . . ." (Triumphs, C.2). In contrast to Mary Magdalene who weeps and wrings her hands, she was the model of patience and equanimity in adversity, and she becomes the model of the consoled. ${ }^{33}$

\title{
Coping with adversity: metaphors of transformation.
}

One is struck forcibly in reading these works by the need and the attempt to 
find a spiritual alchemy that will change pain into joy. To this end they ransack the Bible, Patristic writings and natural lore for metaphors of transformation. This profusion of images is, admittedly, a characteristic of much contemporary prose, but it is nowhere more urgent. ${ }^{34}$ These writers are not only presenting the mysterious paradox of finding life through death, but they are attempting to alter their perception of reality, to mollify affliction by transforming it. The poet Southwell presents the greatest density of metaphor, which is not surprising since his attempt enters the realm of poetry where the magical power of language is used to enchant and to make one behold another truth and a more sublime reality.

Lying behind every work mentioned is the essentially biblical metaphor of the mystical body, developing the relationship between Head and Members whose suffering must be mutual. Equally prevalent is the metaphor of the ship of the Church, worked out in elaborate detail in the manner of the Church Fathers. The Church in tribulation is the tempesttossed ship at sea. Since Christ is both captain and pilot and there are twelve rowers, it cannot fail to reach a safe haven..$^{35}$ Therefore men must weather the storm with hope. This metaphor is perfectly adapted to the needs of consolatio and has itself weathered storms of history. It can encompass such incidents from the gospels as Christ in the ship with his disciples in the Galilean storm or Peter walking on water. Hide so uses it and concludes the sequence: "What now must you do but go to Christ, as his disciples did, awake him as they did, cry unto him, as they did, O Lord, save us" (p. 93). The rich associations that have accrued to this image through Patristic commentary and ecclesiastical tradition make it powerful and compelling. Such use contrasts significantly with John Knoxe's treatment of the "little boat" in his own consolation, where these associations are consciously excluded.

Most common are biblical images of affliction sent by God, such as polishing stones for the temple, hardening pots in the oven, and the refining of gold, and many writers quote Amos' comment that "the sweet presage of a fayre day is a misty morning"' (Floyd, p. 56). Influenced by Augustine's treatment of adversity as medicine, medical images abound. Southwell asserts that damnation is a disease and points out that "where God purposeth to heale, he spareth not to launce ..." (Ep. p. 21), while Persons urges that, since for the sake of bodily health, we "yeelde willingly some part of our blood to be taken from us . . . how much more should we do this for eternal health and salvation of our soules" (Dir. p. 656).

Southwell and Hide in particular use esoteric bits of information from natural history, about beavers, boars, falcons and leopards. Southwell sees God's friends as his favourite hawks kept hooded and fettered because loved: "So dealt God with David . . . yet put he jesses to his Legges" (Ep. p. 12). The leopard conceit is apt and works well in this context: since the leopard so hates even the sight of man, 
to auoyde rage thereof, the custome is to shew unto it a mans picture, in a paper, which it ... teareth assunder . . . Even so is it in the devill and his followers who not being able to wreake their malice agaynst almighty God, ... turne their spite agaynst gods image, that is mans soule. . . (Ep. p. 8)

This idea appears in Basil, but many similar pictures might come from Pliny or contemporary emblem books. There are frequent descriptions of common emblem subjects such as the phoenix, the palm or the camomile. The crushing of coriander represents dismemberment of martyrs to Southwell, who would have seen it as but another divinely-inspired correspondence between nature and the mysteries of God. Persons recites the parables of the competition between the sun and the wind to make a man take off his coat in order to illustrate that the devil's temptations are most effective in time of prosperity. Southwell is the most likely to develop individual images, as in his conventional panegyric of the deceased sister in the Triumphs over Death. She is described as "a pure fish, but yet swimming in muddy streames" for whom "it was not time to drawe her to shoare" (Ep. p. 2). In his poetry we see the alchemy of metaphor working to console, particularly in such a lyric as "Decease, Release" where Mary, Queen of Scots meets her agony with repose, perceiving that

My skaffold was the bedd where ease

I founde,

The blocke a pillowe of eternal reste. ${ }^{36}$

In the same spirit Verstegan transforms anguish into joy by a striking image in which Christ's cross becomes the world's maypole. ${ }^{37}$ The function of such metaphors is almost therapeutic, and they contain the essence of the Christian's hope and the substance of his consolation. Whatever God sends (or Boethius' Fortuna or Alfred's Wyrd), the Christian can be not only invulnerable by conquest of reason, which is the classical ideal, but he can be transfigured by his experience, accompanying Christ through the cross to the resurrection. Persons urges that "If all this doe make us like to Christ crucified: then is there singular great cause why we should take comfort and consolation therein" (Dir. p. 657). Nowhere do these writers advocate the apatheia of the mystics. Suffering is to be tasted and passed through.

\section{English adaptation of consolatory arguments. Recusant adversity: lamentation, exile, imprisonment, death, martyrdom.}

The consolatio of the persecuted Catholic was not merely a call to fortitude or an application of the "moral medication" of the Stoic tradition. It is based on the promise of the Sermon on the Mount, with which Southwell's Triumphs over Death begins: "If it be a blessing of the virtuous to mourne, 
it is the rewarde of those, to be comforted; and he that pronounced the one, promised the other ...." All of these works constantly reiterate Christ's promise that he would send a Comforter, and this distinguishes Christian from philosophical consolation most significantly. Another biblical promise repeated endlessly is the Pauline claim that God will not allow more than a man can endure, even if it means performing miracles. Southwell asserts that for each man there is a passage through the Red Sea when the enemy presses - "the sea will honour a true Israelite" (Ep. p. 147 $)^{38}-$ and he illustrates the same point later when insisting that every pain brings with it a corresponding comfort. So when Stephen was stoned, he "sawe heaven open, and Christ standing on the right hande of his father" (Ep. p. 23'). Associated with this is the argument that comfort would feel less satisfying if man did not first feel pain and desolation. If all this be so, then even the afflicted can, and should, be merry with More, and with Hide feel "iocunditie of spirite in tribulation"' (p. 31). Such acceptance will, consolers claim, puzzle onlookers, several repeating St. Bernard's comment that men "see our afflictions but not ur consolations," for these are private and inward. ${ }^{39}$ Nevertheless, there is always before the English writers the powerful biblical model of the psalmist pouring out his grief and watering his couch with tears. They seemed to appreciate the therapeutic value of lamentation, and, after all, the medieval complaint grew out of Christ's own reproaches on the cross, where even the Son of God questioned his Father's will before embracing it. Though the complaint bewails human misery, it arises out of a positive impulse towards hope and joy. Boethius' dialogue begins with Lady Philosophy's reprimand, "Now is the time for cure rather than complaint" (p. 139). The consolatio pre-supposes lamentation.

Many of the works contain a catalogue of tortures depicting what men must endure. Thomas Pounde echoes that of the hymn Aeterna Christi Munera in his long consolatory poem but it remains merely a list. ${ }^{40}$ Southwell's picture is most effective, building up through graphic detail to the ultimate torture of hell itself, which puts all temporal pain into perspective. But anger comes as much from the fact of injustice as from actual physical causes. Allen's Briefe History begins with a quotation from Boethius: "Pro verae virtutis premiis falsi sceleris poenas subimus," and this is a typical recusant complaint. ${ }^{41}$ Most emotive are Buckland's poetic lamentations where he documents the Catholic's suffering in a personal outburst of rage and pain. In the first of his Seaven Sparkes, God is bombarded with cries for help and accounts of anguish by means of various rhetorical devices. One is moved here by sheer quantity and insistence. The second psalm, which he describes as "conslatorie," assures the reader and the persecuted that God is not asleep or ignorant of their fate, He sees and knows and is deliberately allowing their situation. But help does come, and the scattered flock will be re-united. He is still the good Shepherd.

Interestingly, only H.B. deals at any length with the everyday recusant 
problems such as church attendance and the punishments associated with refusal. This is the substance of his letter and more was supposed to follow. He deals with the threat and the reality of poverty brought about by paying heavy fines, and he meets the recusant's moan with something less than sympathy, pointing out that in the golden days of persecution Christians had nothing to lose since they had sold all to give to the poor. Today, however,

a mole hill appeareth more than a mountain did in times past . . . yea more are dismayed at the pinching of their purse, then men would in former age have ben appalled at the tearing of their fleshe \& the breaking of their bones. (p. 15)

In response to actual complaints he exhorts:

Dreade not the flames of penurye in this lyfe, knowing that if you be caste into thys furnace, Christ himselfe wil come and joyne in companie with you, causing this fervent flame of worldlye wante, to become lyke a freshe ayre of comfortable dewe, by spiritual comfort through his grace . . . . (p. 109)

In the poetry, this element of lamentation fuses with the pervasive Elizabethan elegaic mode. The popular lyric "Tichborne's Elegie," found in numerous printed and manuscript collections, expresses this most generally and most effectively. ${ }^{42}$ Many other lyrics communicate the same sense of waste and loss, rather than a cry of pain in torture. While love-poets of the day made their imaginary moan, the persecuted Catholics in real anguish made their poetry out of suffering, having first ascertained along with Persons that "It is lawfull and allowable refuge delivered us by nature herselfe to mourne and bewayle in time of affliction ...' (Ep. p. 4).

The physical dispersion of English Catholics was a constant source of pain, and allusions to it are poignant. Here again the theme of exile blends naturally with the native literary temper. It is a theme as old as English poetry itself and one that, from the "Seafarer" and "Deor" onwards, the language has been able to accommodate evocatively. In mood and content, exile poems of a Raleigh or a Southwell suggest that it is a "powerful native tradition." 43 Hide records the wandering of the Israelites as precedent for their experience. But the problem was more psychologically complex than the simple exile motif might suggest. Having acknowledged the dilemma of the Englishman who died in Rome, the recusant still had to cope with Christian teaching that man's real patria was not on this earth. The exile's pain for his native land gives shape to his longing for his spiritual home. Henry Walpole's prison vision considers first how his "Thirstie soule" 
But the next stanza shows that it is not England he yearns for,

from Babilon she would retorne unto her home and towne of peace hierusalem where joyes abound. . . .44

Though he might concur with the self-sufficient Stoic that the wise man knew no such thing as exile, and though he knew that the Christian "cannot be banished from Christ wherever he be"' (Hide, p. 76), yet he longed for a resting place. He realized that in many ways it was easier to be abroad among foreign co-religionists than at home among heretics, despite all the attendant political problems. Many of these consolations appear to be addressed to English Catholics from exile, for example, those of Hide, Walpole, Persons, H.B., though the work of the latter was printed secretly in England.

Imprisonment was an alternative to exile, and it has a long and close association with the consolation. The ripe wisdom of men willingly deprived of freedom and ready to die has special potency, as witnessed by the continuing fascination with More's Tower works. Last letters to friends and coreligionists have something about them of the "last words" of epic heroes, and so have particular poignancy. Most of those included in Allen's Briefe History proclaim the success of consolatory arguments and attest the faithfulness of the divine consoler. So with more than Stoic quietness, Sherwin speaks of the mental repose he has experienced since his death sentence was known, commenting that "neither the sharpnes of the death hath much terrified me, nor the shortnes of life much troubled me." 45

Hide sees imprisonment as a sustained martyrdom. At the same time he recognizes that the earth - England itself - is a prison and freedom comes only through death. It was an era when many men of all persuasions were in and out of prison, and it is not strange that Boethian meditations on freedom of the mind were common, both secular and religious. Southwell's treatment of prison is vivid and practical in his letter to "Gods prisoners." He sees it as an honour to be imprisoned for the one true faith, and he stresses how vital the exclusive rightness of their cause is to the justification of their suffering. This idea is dwelt upon in Walpole's Briefe Admonition, where he insists upon conformity, while Hide stresses that unity brings consolation to the confined. Southwell assesses compensations that imprisonment can bring to the just. It is a marvellous opportunity for prayer and contemplation, and it effects in practice the renunciation of the world undertaken in baptism. In this state God is with his children most specifically, transforming the cell into a royal court. Southwell effects this change in the same way as in his Christmas poem where the stable and the stall become Christ's palace and chair of state. ${ }^{46} \mathrm{He}$ gives numerous examples of biblical 
prisoners and records all the great prison events, concluding that "prison is a schoole of divine and hidden misteries, to Gods frendes . . . and a cell of repentance to carelesse offenders"' $(E p$. p. 106 $)$.

Many recusant lyrics have a prison setting and express diverse reactions to imprisonment. Henry Walpole yearns for his "prisoned mynd" to be "out/ of chains and fetters of the flesh" and to achieve this freedom he concentrates on the vision of the new Jerusalem. Two poems by Francis Tregian lament his isolation from his loved ones. ${ }^{47}$ The "Prayer in Prison" also shows deep fear about his own resolution, and his letter to his wife assures her that the "doleful mynde" is "restored to mirthe, / By perfect prayer," and he invites her to be united with him in such prayer. In "Captivitie" Lord Vaux gives vent to the pain of deprivation, each stanza concluding:

Is this a life, nay death you maie it call

That feeles eche payne, and knowes no joye at all..$^{48}$

The same themes recur elsewhere. The cell either is a tomb or else prepares man for one. Behind all this is the belief fiercely acclaimed by Southwell that "Our prisons preach, our punishments converte, our deade quarters and bones confounde your heresye"' (Ep. p. 197').

Imprisonment held little terror for More, but he records with deep feeling his fear of death and of physical pain. This is something not found in traditional consolatio, and it gave his work special efficacy for Catholic prisoners who followed.

The consolatio itself grew out of the traditions of funeral oratory where the purpose was to celebrate the deceased and to give the bereaved a perspective on life and death. It was conventional to argue the futility of mourning. The established view of the genre was that death was "finis aut transitus." Grief was therefore inappropriate, "to weep for one who is happy is envy; for one who does not exist, madness." 49 For Christian writers the issue is more certain and more rich. Southwell shows fine common sense in treating death simply as the passage from this life to the next, and of the manner of death he observes that "Goliath was as much hurt by Davids little stone as Samson by the weight of the whole house. One death, is no more death than an other and as well the easyest as the hardest, taketh our lyfe from us"' (Ep. p. 123) ${ }^{50}$ Floyd's strangely moving document, his Word of Comfort, considers the fact of sudden, violent and accidental death as an instrument of God's wisdom. The "fatal Vespers" or "doleful evensong" as the incident was described by puritan opponents, brought to Floyd's mind that strange case of Tobias who "was strucken blind with swallowes dung falling into his eyes, when coming home from burying bodyes of the faithfull that had been slayne"' (p. 7). Man cannot understand the peculiar purposes of God, whose custom is ever "to send strange disasters upon his servants"' (p. 8). 
The traditional consolatio usually recited the examples of deaths to be admired or condemned. Recusant consolations also celebrate the deaths of the just, using historical figures and contemporary models from among the frequent martyrdoms in England. The inner torment of the wicked is demonstrated with more satisfaction than one might wish in Southwell's catalogue, beginning with Nero and ending with Elizabethan pursuivants. Those who dealt with Boethius contrasted his cruel but serene end with that of his persecutor, Theodoric. $^{51}$

The recusant consolation sometimes incorporates elements of the ars moriendi, teaching men how to die and accept mortality. The concern with the process of death and torture is perhaps the most significant addition to the genre. Though Boethius' own death was cruel in the extreme, he does not deal with the issue. English Catholic consolers, however, employ every rhetorical device to persuade men of the glory of martyrdom which to Southwell is "this crown our greatest enemies set upon our heads" (Ep. p. 162). The day of death is always referred to as the birthday and Fisher saw it as his marriage day. All the comforts for the martyr are marshalled: martyrdom ensures eternal memory and fulfills all the mysteries of baptism, as Saints Augustine and Thomas demonstrate, for it enacts the perfect imitatio Christi through the "baptism of blood." In a passage of balanced antitheses, Southwell develops Tertullian's contrast:

\begin{abstract}
baptisme taketh away our falte, \& martirdom our frayltye, baptisme geveth us the keye, but martirdome letteth us in. That maketh us members of the militant, this of the tryumphante Churche, that geveth us force to walke to our iourneis end, and to fight for the victorye, but this setleth us in repose and crowneth our conquest. Baptisme bringeth us forthe as the mother doth the children ... But martirdome bringeth us forthe as the Lyonesse doth her whelpe. (Ep. p. 140)
\end{abstract}

The section culminates in the acclamation, "these considerations are enough to encourage us to be greedy for martyrdom." This is felt by recusant writers to be the most sublime theme towards which all the others move. At the same time they emphasize with Hide that "you may be Martyrs without stroke of sworde, if you keepe patience in your hearts" (p. 88).

\title{
Stylistic qualities of recusant consolation.
}

Much of the prose is brief and business-like, since there is no leisure for art in the admonitions and exhortations urgently written and dangerously distributed. It is a body of literature written by and for men of action. Even so, there is a force and eloquence born of intense emotion that can make even pamphlets compelling, while avoiding many of the faults of much pamphlet controversy. There is no slander, for example, and no personal malevolence. Heretics may appear constantly in bestial terms but they are 
general and allegorical. It does not take comfort in vengeance, in contrast to the carefully justified "just" revenge of John Knoxe's consolation. All emphasize that it is God's quarrel and He will revenge His own cause. As Michael Walpole's Admonition explains, "we wish for no mans fall that we may arise: we would rejoyce but would have none to sorrow" (Introd.).

Elsewhere writers are more aware of literary traditions and techniques. Fisher, for example, writes in form of a meditation on the moment of death, using a fictitious persona. He describes the work as "a maner of lamentation and sorrowful complayning made in the person of one that was hastily prevented by death." Southwell often adopts the same technique, presenting a dramatic circumstance out of which he will develop a meditation. The scene is composed thus:

Remember howe often you have bene with Christe at his Supper, and reasone nowe requireth you should followe him to Gethsemanie not to sleepe with Peeter, but with him to sweate bloode. (Ep. p. 134)

He often presents a setting with the immediacy urged in Ignatian meditation, as when he insists on the contemplation of the "miseries of our bodies" by means of a visit to the house of the sick, described in graphic detail:

Doe but cast your eyes into one hospitall of lazars, see what cankers, fistuloes, ulcers, and rottings, what wolfes, sores, and festured carbuncles. Wey the miseries of the phrensye, palsey, letargy, falling sicknesses, and lunasye. Consider the diseases of the eyes, eares, mouth . . . consider the infirmityes of the mynde, the furious rages, enuyes, . . . unplacable sorrows, and desperate passions, the continuall hells, tormentes and remorse of conscience. (Ep. p. 59r)

See, weigh, consider: by such imperatives he forces the reader to imagine and to understand. These are devices equally suitable to the exhortation of the preacher as to the solitary reader. Unwittingly, the soul is led into meditation to find comfort.

All the writers show that they are constantly aware of their audience and so establish an intimate and caring relationship. Page by page they address themselves directly to the readers in their distress. Such vocatives are commonest in Hide: "O ye afflicted ... ye that be tempested," "O you persecuted Catholikes . . . you . . . who suffer for justice sake," "O you troubled Christians and you afflicted Catholikes . . .," "O you that lie at home in chains. . . ." Intensity is built up through such invocations and by constant exclamation and rhetorical questions. "O blindness and dullness of harte!' Southwell exclaims stridently,

. . . had you rather have God then man for your enemye? Had you rather lyve captyves here in earth, then dye to be Sayntes in heaven? What are your riches as you use them, but gives to cheyne you, and fetter you in sinne? (Ep. p. 174') 
The reader is pinned down. There is no escape but by assent. Apart from such obvious and popular rhetorical devices, emotion is aroused in other ways, as when Hide pictures extreme domestic conflict, urging:

\begin{abstract}
Though thy nephew a little ladde and playing boy hang about thy necke, though thy mourning mother with rent heares and blubbered cheekes shewe thee her pappes wherewith she gave thee sucke, though they feble father lye at thy thresh holde, passe by thy father, passe by thy mother with drie eyes, and hasten to the crosse of Christ: crultie in this case is the onlye kinds of pietie, and pietie for God is no crueltie. (p. 19)
\end{abstract}

This is as relentless as anything in Foxe's Book of Martyrs.

Elsewhere one senses the relationship with the philosophical medium of the diatribe, which influenced the consolation in its early development. Here the argument is followed through logically and different points of view tested. So Chapter 5 of Southwell's Epistle opens:

\begin{abstract}
But suppose that the pleasures of this world, \& place or state of our lyfe, were such, that they rather invited us to comforte and ioye, then to sorrowe and patient sufferance; yet if we consider what our lyfe hath ben, what our sinns are, what punishments therby we have deserved, we shall thinke god to deale most myldlye with us, and be moste ioyfull of our troubles, which be allotted us, in liew of most intollerable chastisementes. (Ep. p. 55v)
\end{abstract}

He proceeds to examine "what our lyfe hath ben" and why it is not conceivable that men should be called to a life of worldly joy. Persons' discussion of affliction is the most rational and theoretical, where he lists the causes of tribulation and relevant comforts in a systematic way. Others do this mainly in the final summary of their arguments, as in Hide's pithy conclusion. Generally, the burden of proof lies in the appeal to Biblical or Patristic authority rather than in the support of philosophical argument. This is a vital difference between the recusant and the traditional Boethian consolation. In the end, the weight of such argument is profound and the reader is overcome by copious illustration. Very often, however, it is not so much the substance, as the manner of the argument that compels, as in the following advocacy of the via crucis, in which Hide uses simple and obvious rhetorical tricks, in the manner of the preacher, to gain not only assent but imitation:

... if God make you worthy to go that waye, the waye is made easie and playne before you. Christ your head is gone that waye: many thousand Martyrs are gone that waye: old men, young men, children and maydes, are gone that way: Popes, bishops, Priests, Kings, Senators, Counsellors, noble men, noble women, holy widowes, devout virgins, babes and infants are gone that waye. Into that waye you have him to leade you by himselfe, that was made the way for you, Jesus Christ that saide, I am the way. And when you go that waye, your eyes be closed in the persecution of the earth, the heavens be opened to you that be persecuted. (p. 90) 
The hand may be heavy but such fugal word-play has mnemonic and psychological power that serves exhortation well. Much more sparing and condensed and typical of Southwell is his statement that "God woundeth, but his woundes be vulnera amici, woundes of a frinde" (Ep. p. $\left.22^{v}\right)$. This pith and brevity is equally useful in persuasion. Such shaping gives light and shade, bringing ideas into the foreground and giving others depth. In addition to these rhetorical considerations, there is emotive force in the sheer volume of words suggestive of adversity: "affliction," "tribulation," " "persecution," " "misery," "desolation," "vexation," "suffering," "grief," "'groning," "labour," "pain," "calamity," "sorrow," "complaint," "dolour." "Tribulation" is used as often as a dozen times per page, creating its own lexical momentum scarcely impeded or balanced by the language of alleviation: "consolation," "comfort," "solace," "cheer," "patience," "content," "hope," "prosperity." Between these two poles of affliction and comfort the literature moves purposefully, finally transcending both in the wisdom of Christian consolation.

Assured that there is meaning in his condition and believing that there is "no cause more noble" (Hide, p. 10), the persecuted must apprehend the wise counsel of Thomas More's famous prayer, "Gyve me thy grace, good Lord, / To sett the world at nought," where he asks,

to lene unto the cumfort of God,

bysily to labor to love him ...

To bewayle my synnys passed;

ffor the purging of them patiently to

suffer adversitee.

Gladly to bere my purgatory here.

To be ioyfull of tribulations.

To walke the narrow way that ledeth to life.

To bere the crosse with Christ. ${ }^{52}$

More saw his fate and accepted it with open eyes, and he would have agreed with Hide when he cries, "Blessed be the name of God, that adversitie hath opened our eies, which prosperitie had shut" (p. 75).

This is more than Boethius' consolation of philosophy or Gerson's consolation of theology. It comes, as Hide asserts, "out of the body and bosome of religion" (p. 8). The mind may be consoled by philosophical answers and the spirit by the words of Holy Scripture, as Floyd insists, but comfort comes most feelingly from the emotional contact with the divine person. The recusant consolers urge fellowship with Christ in his passion, but also through prayer. Near the end of his Epistle, after urging men to "Aske ... seeke . . . finde . . . and knocke ...," Hides calls upon the Virgin mediatrix and all the Saints to help the persecuted. Here Mary herself becomes "that sweete lady of consolation and queene of comfort" (p. 99) who comes to men's aid by loving intercession rather than by the argument of Lady Philosophy. 
The revival of the consolatory mode in England in the sixteenth century was a direct result of historical events. The Catholic community was under siege and needed at least inner fortification. Persecution intensified after provocative actions such as the excommunication of Elizabeth or the Gunpowder plot. In the 1570's, following Regnans in Excelsis, and after the plot of 1605 , consolatory works are more numerous and urgent. Increased suffering renews the need for shared lamentation and mutual comfort. The Boethian model obviously lies behind most of the literature, but it has been adapted to the changing psychological needs of the post-reformation Englishman in a much larger and less certain European world. Such needs were more practical and specific than could be met by the general, philosophical consolation of Boethius. Recusant consolatory writing is pragmatic and flexible, its power deriving largely from its passion, which is controlled by the restraints of the traditional form.

\section{University of Calgary}

\section{Notes}

1 For a full account see R.C. Gregg, Consolation Philosophy: Greek and Christian 'Paidiea' in Basil and the Two Gregories (Philadelphia, 1975).

2 There were 43 editions in More's lifetime alone, according to Leland Miles. See "Boethius and Thomas More's Dialogue of Comfort,"' ELN, 3 (1965), pp. 97-101.

3 MS. Ashmole, 48, fol. 9v.

4 In The Paradise of Daintie Devises, 1585.

5 In Odes in imitation of the seaven penitential psalmes and other ditties tending to devotion and pietie, Antwerp, 1601 (A. \& R. 844). Here and where relevant, the number in the $A . \& R$. catalogue will be given. A.F. Allison and D.M. Rogers, A Catalogue of Catholic Books in English Printed Abroad or Secretly in England, Biographical Studies, 3, (1956). Contd. from Vol. 4 as Recent History. Reprtd. 1968.

6 English Works of Sir Thomas More, Reprod. in facsimile of the 1557 edition of William Rastell (New York \& London, 1931), Vol. 1.

7 Sir Harry Coningsby, The Consolation of Philosophy, 1664. The copy in the British Library has a dedication to Sir Thos. Hide in which the author describes the sad fortunes of his Royalist family, including details of imprisonment.

8 Sir Richard Grahame, Of the Consolation of Philosophy, 1695. He refers to an earlier Protestant translation by "A Lover of Truth and Virtue," Summum Bonum. An Explication of the divine goodness in the words of. . . Boetius, Oxford, 1674.

9 Sedgefield claims that John Leslie "sent an imitation . . . to his royal mistress is 1572." W.J. Sedgefield, King Alfred's O.E. Version of the Consolation of Philosophy (Oxford, 1900) p. xvii. The D.N.B. records that Leslie himself translated into French his Piae Afflicti Consolationes Divinaque Remedia in 1590.

10 De Consolationae Philosophiae. The Boke of Boecius called the Comfort of Philosophye, London, 1556.

11 Five Books of Philosophical Comfort, London, 1609.

12 The Holy Court, or the Institution of men of Quality with examples of those who in court have flourished in sanctity, Paris, 1626 (A. \& R. 217).

13 Printed in Henry Garnet's The Societie of the Rosary. Newly Augmented, 1596-7 (A.\& R. 355). 


\section{0 / Renaissance and Reformation}

14 The Complete Works of Thomas More, ed. L. Martz \& F. Manley (New Haven \& London: Yale Univ. Press, 1976), Vol. 12, p. 200. The work was first printed in 1553 and was included in the collected edition of 1557. A recension by John Fowler followed in 1573, A Dialogue of Cumfort against Tribulation, . . . Which he wrote in the Tower of London, an. 1534, Antwerp, 1573 (A. \& R. 549, Southern, 42).

15 N. Harpsfield, The Life and Death of Thomas More, Knight . . . Written in the tyme of Queene Marie, ed. E.V. Hitchcock, (London: E.E.T.S., 1932), p. 133.

16 c. 1578 (A. \& R. 304). A Spirituall consolation, written by Iohn Fyssher . . to hys sister Elizabeth, at suche tyme as hee was prisoner in the Tower of London, n.p.d. c. $1578(A . \& R$. 304).

17 Thomas Hide ( $A . \& R .394 \&$ 395). Ensuing quotations will be from the second of these, printed in 1580 .

Robert Persons ( $A . \& R .629)$ Translated out of the French.

18 H.B. not identified but the book came from the same secret press as Southwell's, according to Dr. D.J. Rogers (A.\& R. 59). Robert Southwell An Epistle of Comfort, to the reverend priestes, \& to the honourable, worshipful \& other of the laye sort restrayned in durance for the Catholike faith (A. \& R. 781).

19 Triumphs over Death . . . First written for the consolation of one: but now published for the generall good of all by $R$.S.

20 Persons, $A$ Christian Directorie guiding men to their salvation. In three bookes, Rouen, 1585 (A. \& R. 621).

Granada, Of Prayer and Meditation. Wherein are conteined fowertie devoute meditations for the seven daies of the week . . . Tr. Richard Hopkins, Paris, 1582 (A.\& R. 476).

21 Defence. . ., Rouen, 1584 (A. \& R. 13). Briefe History . . Rheims, 1582 (A. \& R. 7).

22 Walpole, St. Omer, 1610 (A. \& R. 871). Floyd, St. Omer, 1623 (A. \& R. 333).

23 Buckland, Seaven Sparkes of the enkindled soule. With foure lamentations, which composed in the hard times of Queene Elizabeth may be used at all times, when the Church hapneth to be extremely persecuted. 1604-5 (A.\& R. 181).

Pounde, In P.R.O. State Papers, Dom. Eliz. clvii, No. 48, fol. 100. Transcribed by Richard Simpson, part of which is printed in Henry Foley, Records of the English Province of the Society of Jesus (London, 1877, 75-83), Vol. 3, pp. 623-6.

24 Seneca, De Remediis Fortuitorum, 1547. Erasmus, Translated from 'De Morte Declamatio," London, 1553. See also his Treatise Persuadynge a man patientlye to suffre the deth of a frende, London, 1532.

25 John Scory, An Epistle wrytten . . . unto all the faithfull that be in pryson in Englande, London 1555 .

George Joye, A present Consolacion for the sufferers of persecution for ryghtwysenes, London, 1544.

John Knoxe, $A$ fort for the allicted, London, 1580.

26 Copley's poem in A Fig for Fortune, London, 1596.

Thomas Alfield, A True Reporte of the death and martyrdome of M. Campion . . . M. Sherwin \& M. Bryan preistes ... 1582.

$(A . \& R .4)$ For authorship of the poem itself, see A.G.R. Petti, “'Stephen Vallenger. A Recusant Poet. 1541-91," Recusant History, 6, No. 6 (Oct. 1962).

27 There are of course various forms of spiritual consolation. To the mystics, consolations are "ineffable blessings," "inner favours" from a divine source (St. Theresa). St. Ignatius insists that the soul seeking union with God is constantly moved between consolation and tears. To most it is a special visitation by God following some inner crisis. In Buckland's Seaven Sparkes, (Psalm 6) it follows conversion and to Vincenzo Bruno it is the experience proper to reconciliation after penance, (Short Treatise on Penance, $A . \& R .176$ ). To all Catholic writers on the subject, the purpose of penance is to "comfort the soul of the sinner" (Persons). Consolation for afflicted consciences was an important concern to later Puritans, but this is a very different phenomenon. All of these are beyond the scope of this paper.

28 See Elliot Rose's discussion of such spirituality in Cases of Conscience. Alternatives Open to Recusants and Puritans Under Elizabeth 1 and James 1 (Cambridge, 1975). 
29 Perhaps an allusion to both Seneca's "Pauper es quia videris" and Boethius' "nihil est miserum nisi cum putes."

Seneca's De Remediis Fortuitorum' and the Elizabethans, ed. R.G. Palmer, Instit. of Elizabethan Studies, 1 (Chicago, 1953) p. 48.

A.M. Boethius, Philosophiae Consolationis, Loeb Classical Library (Camb. Mass. \& London, 1973) Bk. 11. IV, p. 194.

30 See the study of C.E. Trinkaus, Adversity's Noblemen. The Italian Humanists on Happiness, Columbia University Studies in History, Economics and Public Law, No. 75 (New York, 1940).

31 See R.W. Battenhouse, Shakespearian Tragedy. Its Art and Christian Premises (Indiana, 1969). Battenhouse points out that many of Edgar's speeches are conventionally consolatory.

32 Of Prayer and Meditation, p. 122. The British Library copy is heavily underlined at this point, as indeed are many contemporary works when dealing with the subject of suffering.

33 See Luca Pinelli, The mirrour of religious perfection . . . Tr. Everard, St. Omer, $1618(A . \& R$. 302).

34 See A.C. Southern's discussion in Elizabethan Recusant Prose (London and Cambridge, 1950), p. $208 \mathrm{ff}$.

35 Such analyses follow commentaries such as those of Augustine and Ambrose.

36 The Poems of Robert Southwell, S.J., ed. J.H. McDonald and N. Pollard Brown (Oxford: Clarendon Press, 1967), p. 47.

37 'Invention of Christs Crosse,' Odes in imitation of the seaven penitential psalmes . . . Antwerp, 1601, p. 91.

38 Catholic writers often reflect this association with the Israelites in exile. See for example the work of Ralph Buckland and my article "Jerusalem and Albion. Ralph Buckland's Seaven Sparkes of the Enkindled Soule," forthcoming in Recusant History. Joseph Kernan comments on the same identification in "The Elizabethan Motet," Studies in the Renaissance, IX, (M 62).

39 "Cruces vident, consolations non agnoscunt." St. Bernard is speaking about the secular judgement on the ascetic life.

40 'A Consolation to afflicted Catholikes.'

41 "'Instead of being rewarded for the good I did, I am punished for the evil I did not do." Loeb edition, Bk. 1, IV, p. 154.

42 'Tychbournes Elegie, written with his owne hand in the Tower before his execution,' Verses of Prayse and Joye, London, 1586. It is also found in numerous MSS.

43 See. E.W. Williams, "The Theme of Exile in Renaissance Lyrics: A Perspective on Two Sonnets of Walter Raleigh," ELN, 42 (1975), p. 174.

44 'The description of the heavenly Jerusalem." Add. MS. 15, 225, ff. $39-42^{\mathrm{v}}$. There is a modified text in The Song of Mary Mother of God, London, 1601. The text is most easily accessible in Louise I. Guiney, Recusant Poets (New York: Sheed \& Ward, 1939), p. 155.

45 William Allen, Briefe History. . . p. 82.

46 'New Prince, new Pompe," Poems of Robert Southwell, p. 16.

47 Both poems from the Tregian Yate MS. at Oscott College. 'Letter from Prison,' pp. 124-130. 'Prayer in Prison," pp. 121-124.

48 From the Paradise of Daintie Devises and in various MSS. This collection of poems shows how popular a theme fortitude in adversity was at this time.

49 Seneca to Polybius 9.23 . ". . . to weep for one who is happy is envy, for one who does not exist, madness." Quoted in J.W. Sevenster, Paul and Seneca (Leiden: Brill, 1961), p. 224.

50 The early meditations of Southwell suggest that he worked hard to gain such equanimity. See his Spiritual Exercises and Devotions, ed. J.M. de Buck (London, 1931).

51 Caussin so treats Theodoric. Southwell's list is similar to that of George Joye who moves from Dioclesian to the great Reformation enemy, Thomas More!

52 Thomas More's Prayer Book, ed. L. Martz \& R.S. Sylvester (Yale University Press, 1969). 